\title{
The Impact of Australian Consumer Price Index on the Exchange Rate of Australian Dollar - Chinese Renminbi
}

\author{
Maoguo Wu $(P h D)$ \\ Yue Yu (Master Candidate) \\ SHU-UTS SILC Business School, Shanghai University, China
}

doi: 10.19044/esj.2017.v13n22p12 URL:http://dx.doi.org/10.19044/esj.2017.v13n22p12

\begin{abstract}
This paper investigates the impact of Australian consumer price index on Australian dollar - Chinese renminbi exchange rate. As two major economies in Asia Pacific, China and Australia are conducting ever-increasing volume of economic transactions. Massive Chinese investment, particularly in properties, has caused steady increase in Australian consumer price index and the exchange rate of Australian dollar - Chinese renminbi. Recent slowdown of Chinese economic growth and Chinese investment in Australia caused both Australian consumer price index and the exchange rate of Australian dollar - Chinese renminbi to fall significantly. This paper utilizes data from May 2005 to January 2016 and empirically tests the relation between Australian consumer price index and the exchange rate of Australian dollar - Chinese renminbi. In compliance with classical theories of exchange rates, empirical results find that a negative relation exists between Australian consumer price index and the exchange rate of Australian dollar - Chinese renminbi.
\end{abstract}

Keywords: Exchange Rate, CPI, VAR, VECM

\section{Introduction}

In today's open economy, each country's primary goal when formulating macroeconomic policies is to pursuit a stable price level. A stable price level is also an important guarantee for a country to achieve a balanced economy. Changes in the Consumer Price Index (CPI) is closely linked with changes in exchange rates. Exchange rates between countries are fundamentally determined by each magnitude of value of correlation. According to the theory of Purchasing Power Parity, the value of a foreign currency is primarily determined by the purchasing power of the currencies of the two countries in their respective countries. Einzig (1935) also notes that exchange rate movements may also affect a country's consumption level. 
China has become a core in global economic development. Meanwhile, Australia is one of the most important economies in Asia Pacific. The geopolitical and economic relations between these two countries have witnessed rapid development in recent years. With the implementation of "China - Australia Direct Currency Transactions" (2013) and FTA between China and Australia, the economic linkage between China and Australia has been significantly enhanced.

China has become Australia's major exporting country (Australian Department of Foreign Affairs and Trade, 2010). Chinese investment in Australia keeps increasing. The recent investment boom, i.e., Chinese buying properties in Australia, has significantly raised local housing prices. Australian CPI survey finds that housing accounts for about $24 \%$ of the basket of goods and services in calculating CPI in Australia, while housing only accounts for $13 \%$ in Chinese CPI. The exchange rate of Australian dollar - Chinese renminbi has been rising steadily due to continuous Chinese investment in Australia. Nevertheless, China experienced the slowest economic growth rate in the past decade, merely $6.9 \%$, during the second quarter of 2015. With massive purchasing of properties by Chinese investors coming to a temporary halt, Australian CPI for the first time in years declined. Subsequently, the exchange rate dropped drastically from 7.2 Yuan/Dollar before April 2015 to 4.5 Yuan/Dollar in June 2015. Based on the fact mentioned above, this paper investigates the impact of Australian CPI on the exchange rate of Australian dollar - Chinese renminbi. This paper contributes to existing empirical literature on the long-term relation between CPI and exchange rate.

The remaining part of this paper is organized as follows. Section 2 reviews related literature. Section 3 introduces the data. Section 4 is devoted to empirical analysis. Section 5 concludes the paper.

\section{Related Literature}

After the collapse of the Bretton Woods system, exchange rates between countries fluctuate violently. Research on exchange rate passthrough has become a hotspot of international economic research. A great deal of research investigates exchange rate fluctuation, determining factors of exchange rate, degree of transmission of price level, and the impact of exchange rate fluctuations on domestic price level. A partial selection of previous literature is summarized below.

A large number of papers pertain to the impact of macroeconomic environment factors on exchange rates. Macroeconomic environment and monetary policy are found to be the main factors that influence fluctuation of exchange rates. Chen, $\mathrm{Ni}$, and Wang (2008) argues that China's exchange rate transmission effect decreases with decreasing average inflation and has 
different exchange rate transmission effects in different inflationary environments. Huang (2014) further enriches this theory. It argues that the transmission effect of exchange rate at a time before and after a time node is a structural change. Before the time node, the transmission effect of the exchange rate is greater. After the time node, the transmission effect is drastically reduced. Nevertheless, it agrees that inflation has a significant positive impact on the transmission effect of exchange rates. The difference is that, compared with the norm that the coefficient of the exchange rate transmission is negative, it is found to be positive. Feng, Bi, and Yang (2013) believes that the coefficient of exchange rate transmission throughout the sample period is negative, i.e., the exchange rate of domestic prices has a reverse conduction, and exchange rate appreciation leads to lower prices. However, Lu, Zhang, and Cao (2013) conducts empirical analysis utilizing the same data, but finds a positive sign of the coefficient of the exchange rate transmission. Ni, Li, and Pan (2012) and Huang (2014) reach the conclusion that the coefficient of exchange rate transmission can be both positive and negative in the sample period. In fact, the finding that the coefficient of exchange rate transmission is positive needs special attention. This means that the positive changes in exchange rates lead to the same level of changes in price. In other words, the appreciation of the exchange rate at a time not only inhibits inflation, but also it plays a role in leverage. This is very similar to findings of Wang et al. (2012). In fact, it can be considered that the there is no absolute positive correlation or absolute negative correlation between exchange rate change and the domestic price level.

In recent years, most research on foreign exchange rates have been dominated by research in perspective of traditional open macroeconomics. It is assumed that the market is perfectly competitive and completely free trade. Taylor (2000) argues that the exchange rate transmission effect is endogenous to inflation and a lower inflation environment leads to lower exchange rate, and vice versa. Gagnon and Ihrig (2004) studies the effect of exchange rate on CPI in industrialized countries, as well as marked decline in inflation and exchange rate effects under prudent monetary policy. Bouakez and Rebei (2005) examines the effect of monetary policy on exchange rate transmission effect of Canada and concludes that changes in monetary policy are the main factors of the decline of the exchange rate effect. Choudhri and Hakura (2001, 2006), Devereux and Yetman (2002, 2008) examine the role of inflation variables in interpreting differences in coefficients of exchange rate transmission between countries and find that these variables have provide robust explanation for the decline in exchange rate transmission effect. In addition, Devereux et al. (2003), Sekine (2006), Michele Ca 'Zorzi et al. (2007) perform similar tests following Taylor (2000) and reach the same conclusion. Nogueira Jr. and Leon - Ledesma (2007) 
examines the relation between exchange rate transmission effect and inflationary environment in emerging and developed countries, and finds that the exchange rate transmission effect is affected by inflationary environment and has significant nonlinear characteristics. A lower inflation environment corresponds to a lower exchange rate effect. Holmes (2009) also finds that inflation has a significant nonlinear effect on exchange rate transmission effect.

However, empirical analysis shows that the transmission mechanism of exchange rate changes to domestic prices in different countries are different even in such a simple supply and demand model. Dwyer, Kent and Pease (1993) finds that Australia's exchange rate mechanism tends to be complete in the long run, but it is incomplete in the short run. Dellmo (1996) finds that exchange rate movements have a relatively small impact on the Swiss CPI based on the study of Swiss data, while Switzerland is recognized as a representative of a small and open economy. Corbo and McNelis (1989) argues that economic openness affects domestic price levels. With the opening of a country to deepen its economic level, trade barriers reduce, and more and more industrial products become traded goods, so the overall price level begin to follow the "law of one price". However, even if restrictions on international trade are eliminated, domestic factors can still affect the price level.

Previous research reveals that exchange rate and inflation are endogenous in a perfectly competitive and free market. It is generally agreed that in different inflationary environment, the exchange rate level is not the same. In general, previous research can be divided into two trends. One trend is that positive changes in exchange rates have a reverse conduction on domestic prices, and the other trend is that the exchange rate appreciation promotes the price level of the rise. Taking into account of special circumstances of China, no absolutely positive or negative correlation between exchange rate and domestic price level are observed. Previous literature unanimously finds a negative relation between consumer price index and the value of home currency. Nevertheless, almost all previous literature investigates the exchange rates of US dollars. Research on the exchange rate of Australian dollar - Chinese renminbi is scanty. This paper attempts to fill in the gap by empirically investigating the impact of Australian CPI on Australian exchange rate.

\section{Data}

Classical theories of exchange rates (Purchasing Power Parity, Interest Rate Parity, Balance of Payment Theory, and DDAA Model) stipulates that differences in inflation rates, differences in interest rates, differences in GDP growth rates, and balance of payment are the major 
factors that influence exchange rate. Following theories, proxies of the four influencing factors are included as the four main explanatory variables in empirical analysis.

The data are gathered from People's Bank of China and the database of NetEase. The data set consists of monthly data from May 2005 to January 2016, adjusted in terms of May 2005 as the base period, for a total of 129 observations. Exchange rates (ExR) are average monthly exchange rates of Australian dollar against Chinese renminbi. Differences in inflation rates (CPI) are calculated as the differences between Chinese inflation rates and Australian inflation rates. Similarly, differences in interest rates (IR) are calculated as the differences between Chinese 1-year interest rates and Australian 1-year interest rates. Since GDP is calculated at a quarterly interval, while all variables in the empirical analysis are monthly data, differences in GDP growth rates (GDP) are the differences between Chinese industry value added and Australian industry value added. Balance of payments (BOP) are Australian monthly net import, measured in millions of Australian dollars.

The sample is based on figures from China's floating exchange rate policy in 2005, squaring up the impact of exchange rate on prices with the degree of opening up international trade. The real exchange rate and SDR exchange rate place more emphasis on the balance of payments and the exchange rate. The core explanatory variable of this paper is differences in inflation rates, calculated as the differences between Chinese inflation rates and Australian inflation rates. In order to avoid the interference of other control variables to the core explanatory variable, this paper chooses the nominal exchange rate which is the most widely used in the foreign exchange market as the explanatory variable. Exchange rate data are all official exchange rates published by Bank of China.

Data of CPI are gathered from NetEase Statistics Database. Inflation rates are calculated from CPI, i.e., the rate of change in consumer price index of two adjacent months, with May 2005 being the base group.

China's interest rate data are gathered from People's Bank of China, the central bank of China, while the Australian interest rate data are gathered from the Reserve Bank of Australia. The interest rate differential is obtained by calculating the difference between the Australian interest rate and the Chinese interest rate.

GDP data are gathered from NetEase Statistics Database. GDP growth rate from the previous time period is set as the reference.

Data of balance of payment are gathered from NetEase Statistics Database. Balance of payment is calculated by subtracting China's monthly data from Australia's monthly data, which shows Australia's monthly trade deficit. 


\section{Empirical Analysis}

Statistical Description of Variables

ExR is the explained variable. CPI, IR, GDP, and BOP are explanatory variables. Table 1 shows statistical description of variables.

Table 1 Statistical Description of Variables

\begin{tabular}{cccccc}
\hline \hline Variable & Obs & Mean & Std. Dev. & Min & Max \\
\hline \hline ExR & 129 & 6.0930 & 0.7183 & 4.3828 & 7.5984 \\
CPI & 129 & -0.8903 & 1.5992 & -6.5700 & 2.9300 \\
IR & 129 & 1.0478 & 1.4632 & -1.2500 & 3.4200 \\
GDP & 129 & -0.0084 & 0.0378 & -0.0662 & 0.0773 \\
BOP & 129 & 2577458 & 1798660 & -52979 & 6899742 \\
\hline \hline
\end{tabular}

\section{Stationary Test}

All variables are in time series format. In order to avoid spurious regression and ensure the validity of prediction, all variables undergo a serial of preliminary tests to verify attributes. All variables are tested for stationarity first. Figure 1 shows the trend of the original sequence of all variables.

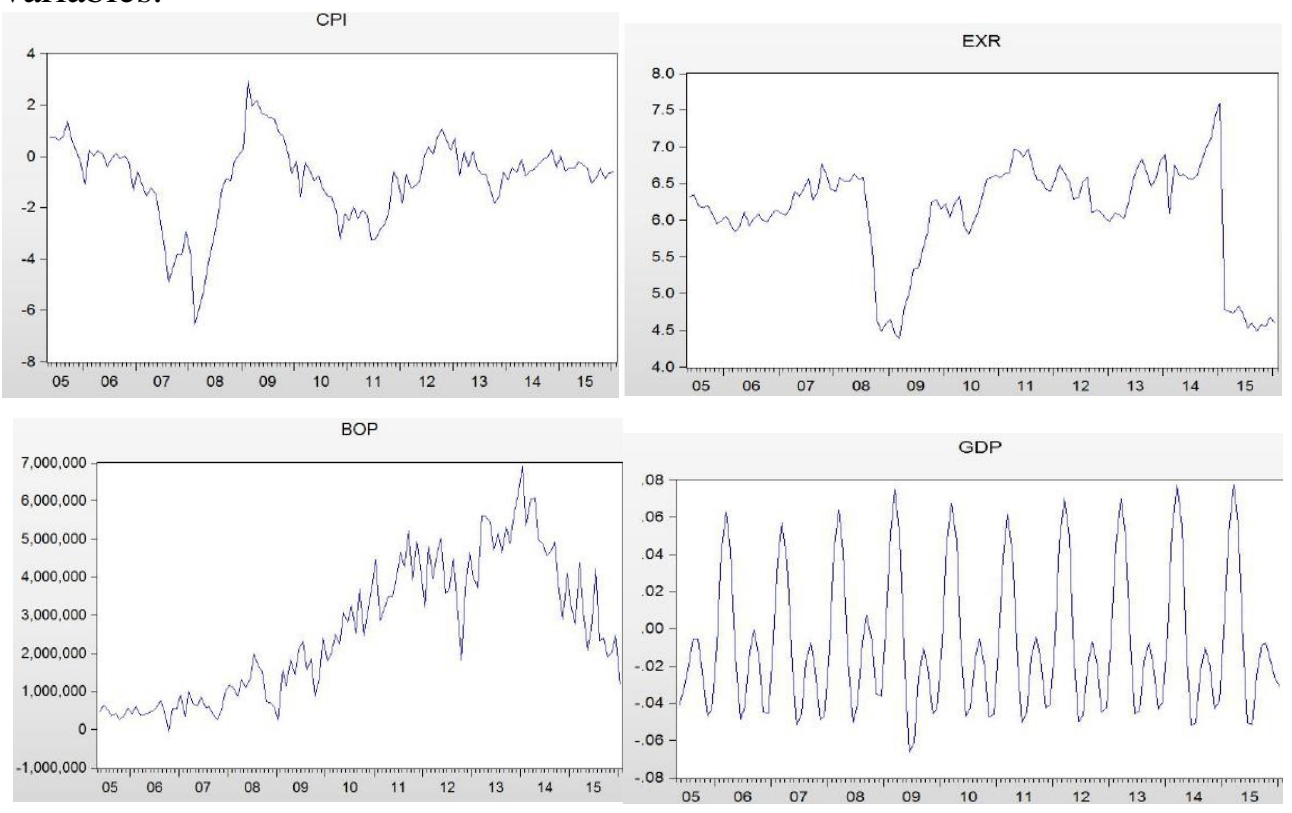

IR

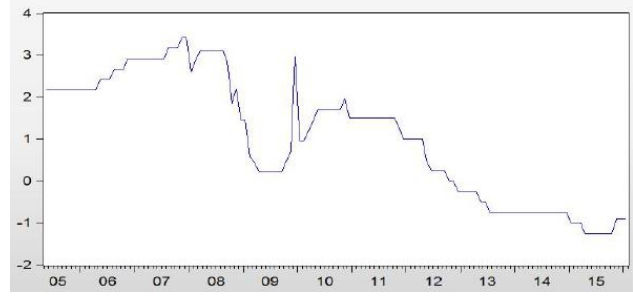

Figure 1 Trend of Variables 
It can be found in Figure 1 that ExR, IR, and BOP have unit root. Further tests for stationarity are conducted using Augmented Dickey-Fuller (ADF) test. The results are shown in Table 2.

Table 2 Unit Root Test

\begin{tabular}{cccccc}
\hline \hline \multirow{2}{*}{ Variable } & \multirow{2}{*}{ Prob. } & \multirow{2}{*}{ t-Stat } & \multicolumn{2}{c}{ Critical Value } & \multirow{2}{*}{ Conclusion } \\
\cline { 4 - 5 } & & & $1 \%$ & $5 \%$ & \\
\hline \hline ExR & 0.203 & -2.212362 & -3.482035 & -2.884109 & Non-Stationary \\
CPI & $0.0232^{* *}$ & -3.187708 & -3.487550 & -2.886509 & Stationary \\
IR & 0.6515 & -1.249306 & -3.482453 & 2.884291 & Non-Stationary \\
GDP & $0.0169^{* *}$ & -3.303950 & -3.486064 & -2.885863 & Stationary \\
BOP & 0.5904 & -1.379439 & -3.482879 & -2.884477 & Non-Stationary \\
\hline \hline
\end{tabular}

As indicated by the test results, ExR, IR and BOP each has a p-value of larger than 0.05 . The unit root's t-test statistic is greater than the critical value of the unit root test at the 5\% significance level. So the null hypothesis is not rejected. It can be seen that these three variables have unit roots, i.e., ExR, IR, and BOP are non-stationary. After taking the first difference of these three variables, unit root test is again conducted on these three transformed variables. Table 3 shows the test results.

Table 3 Unit Root Test of First-Differenced Variables

\begin{tabular}{|c|c|c|c|c|c|}
\hline \multirow{2}{*}{ Variable } & \multirow{2}{*}{ Prob. } & \multirow{2}{*}{ t-Stat } & \multicolumn{2}{|c|}{ Critical Value } & \multirow{2}{*}{ Con. } \\
\hline & & & $1 \%$ & $5 \%$ & \\
\hline d_ExR & $0.0000 * * *$ & -10.96243 & -3.482453 & -2.884291 & Stationary \\
\hline d_IR & $0.0000 * * *$ & -14.68748 & -3.482453 & -2.884291 & Stationary \\
\hline d $\overline{B O P}$ & $0.0000 * * *$ & -13.01051 & -3.482859 & -2.884477 & Stationary \\
\hline
\end{tabular}

It can be seen from Table 3 that the three first-differenced variables, d_ExR, d_IR, and d_BOP are stationary. The three transformed variables can be readily used for further tests.

\section{Granger Causality Test}

Granger causality test is then conducted to test the causal relation between exchange rate and all explanatory variables. Table 4 shows the results. Among all explanatory variables, first-differenced balance of payment and first-differenced exchange rate mutually influence each other, while other explanatory variables one way affect first differenced exchange rate. First-differenced exchange rate is first regressed on these variables which have one-way Granger causality. 
Table 4 Granger Causality Test of Variables

\begin{tabular}{cccc}
\hline \hline Null Hypothesis & F-Stat & Prob. & Conclusion \\
\hline \hline CPI(-1) does not Granger Cause d_ExR & 1.08261 & 0.342 & Do not reject $\mathrm{H}_{0}$ \\
d_ExR does not Granger Cause CPI(-1) & 1.37667 & 0.2563 & Do not reject $\mathrm{H}_{0}$ \\
d_IR does not Granger Cause d_ExR & 1.30044 & 0.2762 & Do not reject $\mathrm{H}_{0}$ \\
d_ExR does not Granger Cause d_IR & 2.91358 & 0.0581 & Do not reject $\mathrm{H}_{0}$ \\
GDP(-1) does not Granger Cause d_ExR & 0.70377 & 0.4967 & Do not reject $\mathrm{H}_{0}$ \\
d_ExR does not Granger Cause GDP(-1) & 1.90472 & 0.1533 & Do not reject $\mathrm{H}_{0}$ \\
d_BOP does not Granger Cause d_ExR & 2.84131 & 0.03237 & Reject $\mathrm{H}_{0}$ \\
d_ExR does not Granger Cause d_BOP & 2.75341 & 0.0473 & Reject $\mathrm{H}_{0}$ \\
\hline \hline
\end{tabular}

Table 4 shows that the p-value of CPI(-1), d_IR and $\operatorname{GDP}(-1)$ are greater than 0.05 so they are insignificant. There is a causal relation between d_ExR and d_BOP, i.e., the explained variable and the explanatory variable mutually cause each other to change. There are quite a large number of factors that may influence exchange rate. Only a partial selection of factors are discussed below.

1. At the $5 \%$ confidence level, there is a two-way Granger cause between d_BOP and ExR. This shows that the balance of payments and the exchange rate between China and Australia on the mutual changes in the future will help explain the modeling analysis in the back need to continue to strengthen the study of the factors.

2. IR cannot reject the null hypothesis at the $10 \%$ significance level, i.e., the exchange rate is the Granger cause of the interest rate, but the interest rate is not the Granger cause of the exchange rate.

3. GDP (-1), CPI and exchange rate do not exist Granger causality.

\section{Regression Equation and Robustness Test}

Although a two-way Granger causality exist between firstdifferenced balance of payment and first-differenced exchange rate, it is innocuous to test the causal relation between first-differenced exchange rate and other explanatory variables without taking into account of firstdifferenced balance of payment, as the main explanatory variable is firstdifferenced inflation rate. Therefore, as a starting point, this paper runs the following regression,

$$
d_{-} E x R=\beta_{0}+\beta_{1} C P I+\beta_{2} d_{-} I R+\beta_{3} G D P+\mu,
$$

where d_ExR is first-differenced exchange rate and d_IR is first-differenced interest rate differences. Regression results and robustness check are shown in Table 5. The results are robust, as explanatory variables in five regressions are all statistically significant. The highest $\mathrm{R}^{2}$ is found in Regression 5, i.e., about $72 \%$ of variation in first-differenced exchange rate is explained by the three variables in Regression 5. 
CPI (or lagged CPI), is found to be negatively associated with exchange rate. First-differenced inflation rate differences and GDP growth rate differences (or lagged GDP growth rate differences) are found to be positively correlated with exchange rate. These findings are in accordance with theory.

Table 5 Regression Results and Robustness Check

\begin{tabular}{|c|c|c|c|c|c|}
\hline Variable & Regression 1 & Regression 2 & Regression 3 & Regression 4 & Regression 5 \\
\hline CPI & $\begin{array}{c}-0.973558 \\
(0.496713) \\
* *\end{array}$ & & & $\begin{array}{c}-0.923146 \\
(0.358364) \\
* * *\end{array}$ & \\
\hline CPI(-1) & & $\begin{array}{c}-1.058739 \\
(0.517296) \\
* *\end{array}$ & $\begin{array}{c}-1.056322 \\
(0.564268) \\
*\end{array}$ & & $\begin{array}{c}-1.051909 \\
(0.536575) \\
* *\end{array}$ \\
\hline d_IR & $\begin{array}{c}0.015937 \\
(0.006167) \\
* * *\end{array}$ & $\begin{array}{c}0.019741 \\
(0.010052) \\
* *\end{array}$ & & $\begin{array}{c}0.007424 \\
(0.000377) \\
* *\end{array}$ & $\begin{array}{c}0.016141 \\
(0.008205) \\
* *\end{array}$ \\
\hline GDP & $\begin{array}{c}4.04 \mathrm{E}-08 \\
(1.53 \mathrm{E}-08) \\
* * *\end{array}$ & & $\begin{array}{c}4.04 \mathrm{E}-08 \\
(1.90 \mathrm{E}-08) \\
* *\end{array}$ & $\begin{array}{c}3.99 \mathrm{E}-08 \\
(1.54 \mathrm{E}-08) \\
* * *\end{array}$ & \\
\hline GDP(-1) & & & & & $\begin{array}{c}0.013463 \\
(0.004151) \\
* * *\end{array}$ \\
\hline $\mathrm{R}^{2}$ & 0.340090 & 0.57281 & 0.370502 & 0.307592 & 0.719708 \\
\hline
\end{tabular}

As can be seen from Table 5, the $\mathrm{R}^{2}$ value of regression 5 is 0.72 , which is much higher than that of other regressions. Therefore, the best result of goodness of fit is selected, the regression equation is as follows.

$$
\begin{gathered}
\text { d_ExR }=-1.051909 \text { CPI }(-1)+0.016141 d \_I R+0.013463 G D P(-1) \\
-0.022039 \\
(0.0345) \quad(0.0367) \\
\mathrm{R}^{2}=0.719708
\end{gathered}
$$

In the above formula, the value of the probability associated with the parameter statistic in parentheses. $\mathrm{R}^{2}$ is equal to 0.719708 , and the goodness of fit indicates that the model can explain $72 \%$ exchange rate change, and the CPI, IR and GDP are all significant. The model shows that IR has negative correlation with exchange rate and GDP has positive correlation, but they all have little effect on the change of exchange rate. CPI and the exchange rate was inversely related while other conditions remain unchanged, CPI increased by $1 \%$, the Australian dollar against the RMB exchange rate performance on the decline of $1.052 \%$ 


\section{Serial Correlation Test}

Since the factors influencing the exchange rate in real life are not limited to the explanatory variables of this paper, there is an inevitable correlation between the variables in the regression equation. Breush-Godfrey LM test finds that Regression 5 has two-ordered serial correlation. To eliminate serial correlation, Regression 5 is augmented with $\mathrm{AR}(1)$ and $\mathrm{AR}(2)$. Breush-Godfrey LM test is conducted again to detect serial correlation afterwards. Test result finds that serial correlation has been eliminated. Table 6 illustrates regression result after eliminating serial correlation. The same causal relation can be found as in Regression 5, i.e., CPI is found to be negatively associated with exchange rate.

Table 6 Regression Result after Eliminating Serial Correlation

\begin{tabular}{ccccc}
\hline \hline Variable & Coefficient & Std. Error & t-Stat & Prob. \\
\hline \hline C & -0.022039 & 0.009638 & -2.286677 & 0.0459 \\
CPI(-1) & -1.051909 & 0.535873 & -1.962982 & 0.0342 \\
d_IR & 0.016141 & 0.007199 & 2.242039 & 0.0397 \\
GDP(-1) & 0.013463 & 0.006276 & 2.145161 & 0.0345 \\
AR(1) & 0.025585 & 0.009202 & 2.780127 & 0.0147 \\
AR(2) & -0.062464 & 0.030245 & -2.065223 & 0.0472 \\
\hline \hline $\mathrm{R}^{2}$ & 0.620506 & & Prob. & 0 \\
\hline \hline
\end{tabular}

\section{Modified Serial Correlation Regression Results}

In order to guarantee the validity of the OLS estimator, the validity of the model is tested by the serial correlation. Therefore, this paper uses Cochrane-Orcutt regression to modify the effect of serial correlation, adding the autoregressive AR (1).

Table 7 Modified Serial Correlation

\begin{tabular}{ccccc}
\hline \hline Variable & Coefficient & Std. Error & t-Stat & Prob. \\
\hline \hline C & -0.012764 & 0.005291 & -2.411964 & 0.0481 \\
CPI $(-1)$ & -0.96467 & 0.477527 & -1.982543 & 0.0214 \\
d_IR & 0.011702 & 0.005496 & 2.128808 & 0.0397 \\
GDP $(-1)$ & 0.011803 & 0.005495 & 2.147285 & 0.0382 \\
AR (1) & 0.025792 & 0.012489 & 2.065223 & 0.0401 \\
\hline \hline $\mathrm{R}^{2}$ & 0.790097 & & Prob. & 0.047603 \\
\hline \hline
\end{tabular}

It can be seen from Table 7 that the linear regression equation with AR (1) has an associated probability of 0.0401 which is less than 0.05 . It falls in the rejection domain. Therefore, the null hypothesis is rejected, meaning that there is no serial correlation. The regression coefficients of each AR are statistically significant.

\section{Autoregressive Conditional Heteroskedasticity (ARCH) Test}

Since the explanatory variables in the regression equation may lack some important economic variables or there are measurement errors, the 
regression equation may be heteroskedastic. In order to avoid inaccuracies in the prediction of the model caused by heteroscedasticity, which reduces the validity of the parameter estimator and leads to meaningless significance test of variables, ARCH test is conducted first. Null hypothesis is that ARCH effect exist among variables.

From Table 8 , the regression equation is found to have a probability greater than 0.05 , so there is no ARCH effect. The regression does not have heteroskedasticity.

Table 8 ARCH Test

\begin{tabular}{ccccc}
\hline \hline Variable & Coefficient & Std. Error & t-Stat & Prob. \\
\hline \hline $\mathrm{C}$ & 0.101858 & 0.056384 & 1.806483 & 0.0733 \\
Resid1/2 & 0.001182 & 0.089800 & 0.013160 & 0.9895 \\
\hline \hline F- Stat & 0.000173 & & Prob. & 0.9895 \\
OBS*R ${ }^{2}$ & 0.000176 & & Prob. & 0.9894 \\
\hline \hline
\end{tabular}

\section{Selection of Lag Period}

Before building a VAR model, it is necessary to determine the number of lag periods in the first step. The choice of lag period plays an important role in the results analysis. If the number of lagged periods is too small, there will be a serious autocorrelation of the error term. If the number of lagged periods is too large, the degree of freedom will be reduced, which affect the effectiveness of parameter estimation.

Table 9 Selection of Lag Period

\begin{tabular}{ccccccc}
\hline \hline $\begin{array}{c}\text { Lag } \\
\text { Order }\end{array}$ & LogL & LR & FPE & AIC & SC & HQ \\
\hline \hline 0 & -1832.159 & NA & $7.1 \mathrm{E}+10$ & 30.6932 & 30.8551 & 30.7449 \\
1 & -1832.673 & 16.1242 & $6.4 \mathrm{E}+10$ & 30.5945 & 30.8733 & 30.7075 \\
2 & -1814.491 & 17.1383 & $6.0 \mathrm{E}+10^{*}$ & $30.5089 *$ & $30.6798^{*}$ & $30.6513^{*}$ \\
3 & -1811.884 & 4.7801 & $6.4 \mathrm{E}+10$ & 30.5314 & 30.9959 & 30.7207 \\
4 & -1808.264 & 6.5591 & $6.8 \mathrm{E}+10$ & 30.5374 & 31.0952 & 30.7614 \\
5 & -1806.997 & 2.2322 & $6.5 \mathrm{E}+10$ & 30.5829 & 31.2337 & 30.8472 \\
6 & -1805.571 & 2.4245 & $6.8 \mathrm{E}+10$ & 30.6218 & 31.3695 & 30.9205 \\
7 & -1803.299 & 3.8753 & $7.0 \mathrm{E}+10$ & 30.6548 & 31.4912 & 30.9458 \\
8 & -1802.358 & $1.5267 *$ & $7.4 \mathrm{E}+10$ & 30.7056 & 31.6351 & 31.0833 \\
\hline \hline \multicolumn{7}{c}{ * denotes the number of lag periods selected by each method criterion. }
\end{tabular}

Table 9 shows the result of selection of the number of lag periods. From the table it can be concluded that, according to the SC criterion (SC value is the minimum), the optimal number of phases of the vector autoregressive model is two. Therefore, two lags are selected as the lag period.

\section{Vector Auto Regression (VAR) Model}

Adding the variable first-differenced balance of payment to the original linear regression function, Vector Auto Regression (VAR) Model is 
utilized to further verify the causal relation between CPI and exchange rate. Table 7 shows the results.

Table 10 VAR Model

\begin{tabular}{ccc}
\hline \hline & d_ExR & BOP \\
\hline \multirow{2}{*}{ d_ExR(-1) } & 0.099033 & -0.043674 \\
& $(0.01093)$ & $(0.019596)$ \\
& {$[2.13604]$} & {$[-2.22868]$} \\
\hline \multirow{2}{*}{ d_ExR(-2) } & -0.023347 & -0.062895 \\
& $(0.047840)$ & $(0.026943)$ \\
& {$[-2.07008]$} & {$[-2.33433]$} \\
\hline \multirow{2}{*}{ d_BOP(-1) } & -1.461389 & 0.843953 \\
& $(0.491336)$ & $(0.09100)$ \\
d_BOP(-2) & {$[2.97432]$} & {$[9.27472]$} \\
& -0.580452 & 0.069189 \\
& $(0.250361)$ & $(0.024949)$ \\
C C & {$[2.31849]$} & {$[2.77317]$} \\
& 0.003871 & -0.087348 \\
& $(0.03516)$ & {$[0.07199)$} \\
d_IR & {$[0.11010]$} & {$[-1.21327]$} \\
& 0.018499 & 0.066832 \\
& $(0.009340)$ & {$[0.19074)$} \\
CPI & {$[1.98057]$} & $-1.35 \mathrm{E}-07$ \\
& $-4.66 \mathrm{E}-08$ & $(8.4 \mathrm{E}-08)$ \\
& $(2.18 \mathrm{E}-08)$ & {$[1.59793]$} \\
\hline \multirow{2}{*}{ GDP } & {$[-2.13052]$} & 0.891163 \\
& 0.028714 & $(1.65657)$ \\
& $(0.014108)$ & {$[0.53796]$} \\
\hline
\end{tabular}

Despite being statistically insignificant, IR, BOP and GDP all have the expected sign. CPI is shown to be negatively correlated with exchange rate. It is noteworthy that exchange rate and balance of payment are shown to mutually influence each other, with the relation being negative.

\section{Impulse Response and Variance Decomposition}

The relative importance of influencing factors of exchange rate is assessed by impulse response function and variance decomposition. Figure 2 reveals that all the characteristic roots of the VAR model are distributed in the unit circle. Hence, the structure of the VAR model is stable. Impulse response and variance decomposition can therefore be carried out. 


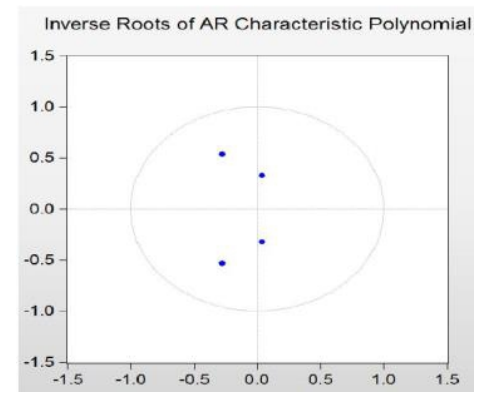

Figure 2 Inverse Roots of AR Characteristic Polynomial

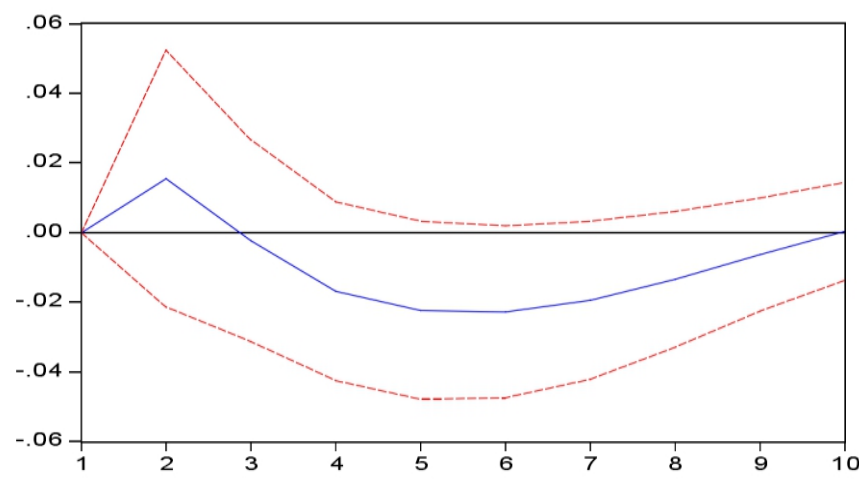

\begin{tabular}{cc}
\hline \hline Period & \\
\hline \hline 1 & 0.000112 \\
& $(-7.50 \mathrm{E}-05)$ \\
2 & 0.000228 \\
& $(-0.00014)$ \\
3 & 0.000276 \\
& $(-0.0002)$ \\
4 & 0.000261 \\
& $(-0.00022)$ \\
5 & 0.000204 \\
& $(-0.0002)$ \\
\hline \hline
\end{tabular}

Figure 3 Response of D_EXCHANGE_RATE to D_BOP

It is clear from Figure 3 that the exchange rate responds positively to the balance of payment. The response peaked in the second period. Afterwards the response begins to attenuate, reaching the minimum value in the sixth period.

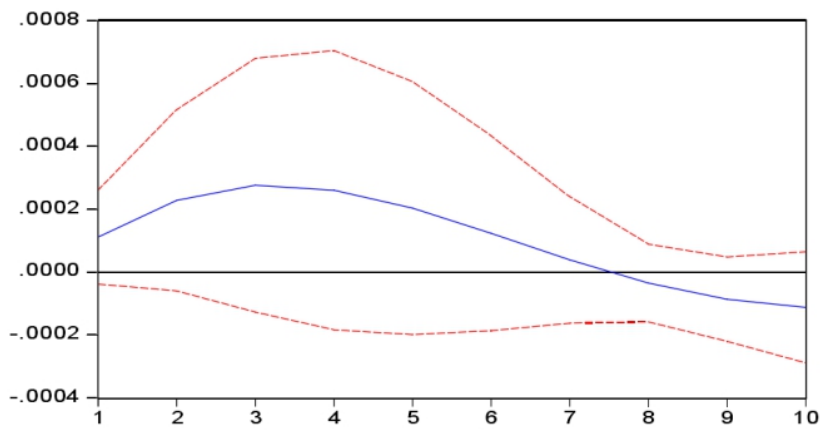

\begin{tabular}{cc}
\hline \hline Period & \\
\hline \hline 1 & 0.000211 \\
& $(-0.0006)$ \\
2 & 0.015521 \\
& $(-0.01845)$ \\
3 & -0.002343 \\
& $(-0.0145)$ \\
4 & -0.016843 \\
& $(-0.01284)$ \\
5 & -0.022325 \\
& $(-0.01279)$ \\
\hline \hline
\end{tabular}

Figure 4 Response of D_BOP to D_EXCHANGE_RATE 
As can be seen in Figure 4, when balance of payment receives an impulse from exchange rate, it positively responds. The response steadily grows until the third period in which it reaches the maximum. Afterwards the response turns negative and attenuates. The response eventually wears away in the seventh period.

\section{Cointegration Test}

In the previous empirical analysis, this paper uses the difference between the Australian CPI and Chinese CPI as the proxy of interest rates. But the inflation environment is also an important factor affecting the exchange rate transmission according to the transmission effect of the exchange rate. That is, there is a positive relation between the inflation level and the exchange rate transmission effect. According to the interest rate parity theory, interest rates in Australia and China will exert an influence on the Australian CPI.

After ADF unit root test, all results do not reject the null hypothesis, but after the first-order difference lies in the rejection domain. Therefore, in order to avoid long-run relation between missing variables, it is necessary to first co-integrate all variables.

Table 11 Cointegration Test Results (Trace)

\begin{tabular}{ccccc}
\hline \hline Null Hypothesis & Eigenvalues & Trace Statistics & $5 \%$ Critical Value & Prob. \\
\hline \hline $\begin{array}{c}\text { cointegrating } \\
\text { vectors }\end{array}$ & 0.401312 & 133.6363 & 137.8264 & 0.1341 \\
1 cointegrating \\
$\quad$ vectors*
\end{tabular}

Table 12 Cointegration Test Results (Maximum Eigenvalue)

\begin{tabular}{ccccc}
\hline \hline Null Hypothesis & Eigenvalues & Trace Statistics & $5 \%$ Critical Value & Prob. \\
\hline \hline $\begin{array}{c}\text { c cointegrating } \\
\text { vectors }\end{array}$ & 0.401312 & 63.61384 & 70.07757 & 0.3789 \\
1 cointegrating \\
$\begin{array}{c}\text { vectors* } \\
2 \text { cointegrating } \\
\text { vectors }\end{array}$ & 0.192657 & 26.53680 & 23.87687 & 0.0341 \\
$\begin{array}{c}3 \text { cointegrating } \\
\text { vectors }\end{array}$ & 0.181100 & 24.77440 & 27.58434 & 0.1099 \\
4 cointegrating \\
$\quad$ vectors
\end{tabular}


As the Johansen test results in Table 8 and Table 9 show, at the significance level of $5 \%$, the trace statistics are 70.022 and 26.536 , respectively, which are larger than the critical value. Therefore, the null hypothesis that there is no cointegration relation is rejected, indicating that there exists cointegration relation among the variables.

Table 13 Standardized Cointegration Parameter

\begin{tabular}{llllll}
\hline \hline ExR & CPI_AU & CPI_CN & GDP_AU & \multicolumn{1}{l}{ IR_AU } & \multicolumn{1}{l}{ IR_CN } \\
\hline \hline \multirow{2}{*}{1.00000} & 2.737744 & 0.206700 & 1.636106 & -2.129356 & 2.943432 \\
& $(1.12410)$ & $(0.08833)$ & $(0.64663)$ & $(0.8663)$ & $(0.79842)$ \\
\hline \hline
\end{tabular}

According to Table 10, there is a stable relation between ExR, CPI_AU, CPI_CN, GDP_AU, IR_AU, and IR_CN in the long run. CPI_AU, CPI_CN, GDP_AU and IR_CN are positively correlated with ExR, while IR_AU is negatively correlated with ExR. All cointegration parameters are significant.

\section{Granger Causality Test Based on Cointegration}

The long-term stability of the variables is verified by the cointegration test, and then the causal relation among variables and the exchange rate is determined by the Granger causality test.

Table 14 Granger Causality Test Based on Cointegration

\begin{tabular}{cccc}
\hline \hline Null hypothesis & F-Stat. & Prob. & Conclusion \\
\hline \hline CPI_CN does not Granger cause ExR & 1.98233 & 0.1422 & Do not reject $\mathrm{H}_{0}$ \\
ExR does not Granger cause CPI_CN & 2.95303 & 0.0559 & Do not reject $\mathrm{H}_{0}$ \\
\hline CPI_AU does not Granger cause ExR & 0.28425 & 0.7531 & Reject $\mathrm{H}_{0}$ \\
ExR does not Granger cause CPI_AU & 4.46232 & 0.0135 & Reject $\mathrm{H}_{0}$ \\
\hline GDP_AU does not Granger cause ExR & 0.90411 & 0.4076 & Do not reject $\mathrm{H}_{0}$ \\
ExR does not Granger cause GDP_AU & 0.90245 & 0.4083 & Do not reject $\mathrm{H}_{0}$ \\
\hline IR_AU does not Granger cause ExR & 0.85731 & 0.4268 & Do not reject $\mathrm{H}_{0}$ \\
ExR does not Granger cause IR_AU & 4.39245 & 0.0144 & Reject $\mathrm{H}_{0}$ \\
\hline IR_CN does not Granger cause ExR & 1.64362 & 0.1975 & Do not reject $\mathrm{H}_{0}$ \\
ExR does not Granger cause IR_CN & 5.53685 & 0.0050 & Reject $\mathrm{H}_{0}$ \\
\hline \hline
\end{tabular}

From Table 11, the Granger causality test results show that IR_AU and IR_CN are not Granger causes of ExR change, but ExR and IR_AU and IR_CN are Granger causes at the significance level of 5\%.That is, there is a one-way Granger causality between ExR and IR. There is a two-way Granger causality relation between CPI and the exchange rate in Australia. Since the causal relation is not exclusively one-way, Vector Error Correlation Model (VECM) is conducted to further explore the relations. 


\section{Vector Error Correction Model (VECM)}

Through the cointegration test to detect the cointegration relation among variables, this paper establishes vector error correction model (VECM) to study the short-term dynamic characteristics among variables. The advantage of this model is that the condition of cointegration constraint is added to the basis of VAR model.

Table 15 Vector Error Correction Model

\begin{tabular}{|c|c|c|}
\hline Error Correction & $\mathrm{D}(\mathrm{ExR})$ & D（CPI_AU） \\
\hline CointEq1 & $\begin{array}{c}-1.000000 \\
(1.2 \mathrm{E}-09) \\
{[-8.6 \mathrm{e}+08]}\end{array}$ & $\begin{array}{c}-0.043700 \\
(0.09275) \\
{[-0.47117]}\end{array}$ \\
\hline $\mathrm{D}(\operatorname{Ex} \mathrm{R}(-1))$ & $\begin{array}{c}0.593014 \\
(0.227647) \\
{[2.60497]} \\
\end{array}$ & $\begin{array}{c}-0.034172 \\
(0.014356) \\
{[-2.380385]} \\
\end{array}$ \\
\hline $\mathrm{D}(\operatorname{Ex} \mathrm{R}(-2))$ & $\begin{array}{l}-0.032714 \\
(0.014852) \\
{[-2.20271]} \\
\end{array}$ & $\begin{array}{c}0.035399 \\
(0.014074) \\
{[2.515208]}\end{array}$ \\
\hline D (CPI_AU(-1)) & $\begin{array}{l}-0.969616 \\
(0.317622) \\
{[3.052727]} \\
\end{array}$ & $\begin{array}{c}0.858543 \\
(0.498732) \\
{[1.721451]} \\
\end{array}$ \\
\hline D（CPI_AU(-2)） & $\begin{array}{l}-0.929515 \\
(0.357853) \\
{[2.597407]}\end{array}$ & $\begin{array}{c}-0.632778 \\
(0.261360) \\
{[-2.421095]}\end{array}$ \\
\hline $\mathrm{C}$ & $\begin{array}{c}-0.006153 \\
(0.002402) \\
{[-2.561613]}\end{array}$ & $\begin{array}{c}-0.310376 \\
(0.125404) \\
{[-2.474993]}\end{array}$ \\
\hline GDP_AU & $\begin{array}{l}-0.292112 \\
(0.148441) \\
{[-1.96786]}\end{array}$ & $\begin{array}{l}-0.310376 \\
(0.149091) \\
{[2.081793]}\end{array}$ \\
\hline ExR & 1.000000 & 0.083566 \\
\hline & $\begin{array}{l}(1.4 \mathrm{E}-14) \\
{[6.9 \mathrm{e}+13]}\end{array}$ & $\begin{array}{l}(0.042585) \\
{[1.962346]}\end{array}$ \\
\hline IR_AU & $\begin{array}{c}0.021914 \\
(0.004101) \\
{[5.343031]}\end{array}$ & $\begin{array}{c}-0.009076 \\
(0.003832) \\
{[-2.368239]} \\
\end{array}$ \\
\hline IR_CN & $\begin{array}{c}-0.071913 \\
(0.027081) \\
{[-2.655467]}\end{array}$ & $\begin{array}{c}-0.081059 \\
(0.029452) \\
{[-2.752257]} \\
\end{array}$ \\
\hline
\end{tabular}

From the results of Table 12, the impact of Australian CPI on the Australian dollar exchange rate is significant and negative. When the Australian consumer price index fell, indicating that the inflation rate decreased, that the purchasing power of the Australian dollar increased, in accordance with the purchasing power parity theory, the Australian dollar should be stronger. 
The impact of Australia's loan interest rate and China's lending rate on the exchange rate is significant. The impact of the Australian dollar is weak, the coefficients being below 0.1 . That is, when the interest rate fluctuations is $10 \%$ then the Australian dollar exchange rate is only $1 \%$.

When Australia's interest rate rises and the cost of production rises, the profitability of enterprises declines. As a result, Australia's macroeconomic growth is weakened, and the decline of Australia's foreign trade leads to a fall in the demand for currency and the decline of the Australian dollar. It is opposite for China's lending rates.

\section{CHOW Test}

The Australian dollar fell sharply in February 2015, falling from a stable 7.2 Yuan per Australian dollar to 4.7 Yuan per Australian dollar by June 2016. Moreover, China's GDP growth slowed and international commodity prices fell at the same time. Therefore, this paper presents a hypothesis: the significant change in China's economic growth and international commodity prices affects the exchange rate.

Based on the singular value of the data, this paper first defines the dummy variable (break), the value of break before August 2015 is defined as 0, and the value after August 2015 is defined as 1. Multiply all the explanatory variables with break to generate interaction terms. All interaction terms along with break are then added to the Cochrane-Orcutt AR

(1) regression, the regression equation being as follows:

$$
\begin{aligned}
\text { d_ExR }=\beta_{0}+ & \beta_{1} \text { d_CPI_AU }+\beta_{2} d_{-} \text {CPI_CN }+\beta_{3} \text { d_IR_AU }+\beta_{4} \text { d_IR_CN } \\
& +\beta_{5} \text { d_GDP_AU }+\beta_{6} \text { d_GDP_CN }+\beta_{7} \text { d_BOP }+\beta_{8} \text { break } \\
& +\beta_{9} \text { break } * \text { d_CPI_AU }+\beta_{10} \text { break } * \text { d_CPI_CN }+\beta_{11} \text { break } \\
& * \text { d_IR_AU }+\beta_{12} \text { break } * \text { d_IR_CN }+\beta_{13} \text { break } * \text { d_GDP_AU } \\
& +\beta_{14} \text { break } * \text { d_GDP_CN }+\beta_{15} \text { break } * \text { d_BOP }+\mu
\end{aligned}
$$

Wald Test is then performed to test the overall significance of the dummy variable (break) and all the interaction terms. The result is shown in Table 13.

Table 16 Overall Significance Test

\begin{tabular}{|c|}
\hline$\beta_{8}$ break $=0$ \\
\hline$\beta_{9}$ break $*$ d_CPI_AU $=0$ \\
\hline$\beta_{10}$ break $*$ d_CPI_CN $=0$ \\
\hline$\beta_{11}$ break $*$ d_IR_AU $=0$ \\
\hline$\beta_{12}$ break $*$ d_IR_CN $=0$ \\
\hline$\beta_{13}$ break $*$ d_GDP_AU $=0$ \\
\hline$\beta_{14}$ break $*$ d_GDP_CN $=0$ \\
\hline$\beta_{15}$ break $*$ d_BOP $=0$ \\
\hline
\end{tabular}


The test result is as follows:

Table 17 Wald Test

$\mathrm{F}(16,113)=3.13$

Prob. $>\mathrm{F}=0.0021$

$\mathrm{P}$ value is 0.0021 which is less than 0.05 , so dummy variable (break) and all interaction terms combined are significantly. Therefore, China's economic slowdown and the international commodity price declines have an impact on the Australian dollar exchange rate.

\section{Policy Implication}

\section{Economic Similarities between China and Australia}

The foreign trade exports of both China and Australia are dominated by primary commodities. Both countries are commodity export-oriented economies. While the export-oriented economy by the external market fluctuations is in the relatively large interference. The instability in the balance of payments also led to the development of exchange rate market instability. Both China and Australia are seeking to move from commodity exports to capital-export-oriented economies.

Both China and Australia are under pressure to restructure their economies. While China's economic transformation is headed toward consumption-driven, Australia is also trying to shift its economic model, which relies on the export of mineral commodities. Because China and Australia are closely cooperating in international trade, to some extent, the adjustment of China's economic development model is bound to have an impact on Australia. China has been trying to get rid of natural resources through the exchange of GDP for the economic development model, and it will strengthen itself as a world industrial power. The breakthrough is the Sino-Australian FTA negotiations. Australia hopes that it can rely on the FTA as an opportunity not only to become a stable energy provider for China, but also to enhance its position as a high-end provider of products, food and services.

The Australian dollar and Chinese RMB are regional currencies, being the fifth and the sixth largest currencies in the world and in the foreign exchange market, respectively. Although in some areas these two currencies have certain influence, but in a global perspective, their influence is still insufficient. The influence of RMB is limited to East Asia and the Middle East region, while the Australian dollar has more influence in South Asia and Oceania region, both countries hope that their national currencies can become a strong currency with a wide influence around the world. 


\section{Implications}

Australia will control the consumer price index in a very low range in a very long period of time. This sets an example for China's policy. The primary goal of China's monetary policy is to maintain the stability of the value of the currency and to promote economic growth. However, in fact, China's monetary policy also includes four major objectives of macroeconomic regulation and control, namely: price stability, full employment, economic growth, and balance of payments. To maintain a reasonable price level requires the central bank to strictly control the money supply. Full employment and economic growth require the central bank to implement an active monetary policy. The balance of payments surplus is conducive to promoting full employment and economic growth, but it will undermine the balance of payments, and ultimately through the increase in foreign exchange channels to influence domestic price level. As the complexity of the RMB monetary policy is large, it is not conducive to the development of a targeted monetary policy. As a result, the effect of controlling inflation is far from satisfactory. The empirical results show that in addition to the consumer price index, the exchange rate effect on other variables is generally small, so the development of monetary policy should highlight its single function.

\section{Conclusion}

\section{The Impact of CPI on Exchange Rate}

This paper studies the relation between the Australian dollar exchange rate and the consumer price index by constructing an empirical model in line with special conditions in both countries, and provides a basis for the empirical study by using theoretical analysis. Through the use of a variety of measurement methods and models for testing the relation between the two, some important empirical conclusions are drawn.

This paper uses the VAR model to study the correlation between the nominal exchange rate of Australian dollar against Chinese RMB between May 2005 and January 2016 and the consumer price index difference between Australia and China. By combining the two models, this paper finds the following conclusions. First, the consumer price index has a negative impact on the exchange rate, i.e., when the consumer price index rose, the Australian dollar fell. The two variables are closely related, and the consumer price index is the main factor that influence Australian exchange rate changes.

But the two models have slightly different conclusions. The impact of China's lending rate on the Australian consumer price index is more significant than that of the Australian loan interest rates. This may be because the Australian economy is dominated by exports of commodities, 
while China is Australia's largest export trading country. If China's interest rates fluctuate, Australia's export demand is shrinking even more than that of Australia's lending rate. Based on the autoregressive impulse response and variance decomposition, this paper further studies the interrelation between the international balance of payments and the Australian dollar exchange rate. It finds that when the balance of payments is shocked, it will be quickly passed to the exchange rate, and the exchange rate also transfer the impact to the balance of payments.

In summary, this paper finds that the consumer price index is the main influencing factor of the exchange rate fluctuation. When the Australian consumer price index rises, the Australian dollar will depreciate.

\section{The Impact of Exchange Rate on Australian Economy}

From the government's point of view, the depreciation of Australian dollar would weaken the competitiveness of the Australian economy. At the same time, as Australia has an export-oriented economy, a strong Australian dollar policy will also cause a drag on the Australian economy. The appreciation of the Australian dollar means that it will exacerbate the downward pressure on the economy and further plunge the already injured Australian mining industry. With the further slowdown in China's economy, the impact on the Australian economy and the Australian dollar will further increase. For the Australian government, the Australian dollar exchange rate policy will be a dilemma.

From the perspective of enterprises, especially enterprises in Australia, in the face of the government to reduce the cash rate of Australian dollar depreciation of the economic policy, with the resulting increase in import costs, will make the competitiveness of local products decline. In order for enterprises to maintain the original profit margins, enterprises are forced to transfer pressure to downstream consumers. Consumers face rising prices, so they may give up these products. This fact further leads to the survival of local enterprises.

For people, the rise in prices of local goods and the rise in the prices of inexpensive Chinese goods will increase the burden on people and deteriorate their quality of life, further exacerbating their pessimistic outlook on the future economy.

\section{References:}

1. Bi, Y., RMB's Exchange Rate Change and Commodity Import Price: An Empirical Analysis Based on VECM, The Journal of Quantitative \& Technical Economics, 2008(08), pp. 70-82

2. Chen, Y., Rogoff, K., Commodity Currencies, Journal of International Economics, 2002(08), vol. 60, pp. 176-183 
3. Elaine, C., Marion, K., Christine, L., The Exchange Rate and Consumer Price, Bulletin, 2011, pp. 1-16

4. Kenneth, W. C., Renee, F., Commodity Currencies and Currency Commodities, Resources Policy, 2008, vol. 33, pp. 55-73

5. Ni, K., Cao, W., The Theoretical and Empirical Study of the Incomplete Pass-Through of RMB Exchange Rate Fluctuation, Journal of Financial Research, 2009(06), pp. 44-59

6. Nogueira, R. P. Jr., Inflation Targeting and the Role of Exchange Rate Pass-Through. Studies in Economics, No. 0602, June 2006, Department of Economics, University of Kent

7. Paul, C., Luis F. C., Ratna, S., Commodity Currencies and the Real Exchange Rate, Journal of Development Economics, 2004, vol.75, pp.239-268

8. Xiang, H., Xu, L., Is There "Native Features" in the Relation between the Exchange Rate Pass-Through and the Inflation, Journal of Financial Research, 2011(11), pp. 74-87 